\title{
EFFECT OF DIFFERENTIAL SETTLEMENT ON FRAME FORCES - A PARAMETRIC STUDY
}

\author{
Atishay Lahri ${ }^{1}$, Vivek Garg ${ }^{2}$ \\ ${ }^{1}$ UG Scholar, Department of Civil Engineering, Maulana Azad National Institute of Technology, Bhopal, Madhya \\ Pradesh, India \\ ${ }^{2}$ Assistant Professor, Department of Civil Engineering, Maulana Azad National Institute of Technology, Bhopal, \\ Madhya Pradesh, India
}

\begin{abstract}
The dynamic nature of loads, seasonal variation of soil properties, uneven soil strata below footings or inappropriate design of foundation makes differential settlement inevitable. Differential settlement is largely responsible for developing forces or changing the existing forces in the structure and is often considered as the underlying cause of many structural failures. A structural engineer has to take into account these forces while designing the structure. Different structural parameters like stiffness of columns and beams and number of storeys and bays affect the response of the structure to differential settlement. In the present study, a plain portal frame subjected to constant differential settlement of $10 \mathrm{~mm}$ is analyzed for different cases using a structural analysis software i.e. STAAD Pro. Different parameters of the frame are varied to understand their influence on frame forces developed due to differential settlement. The parameters taken into account in this study are length of beam, height of column, moment of inertia of beam and column and number of storeys and bays. It is found that the forces in the frame developed due to differential settlement decrease on increasing beam lengths and column heights. Also, decreasing the moment of inertia of beams and columns is effective in reducing these forces. In addition, differential settlement tends to affect forces more in lower storeys as compared to higher storeys. The frame forces are more prominent for bays which are near to the support subjected to settlement. The increase or decrease in frame forces due to differential settlement can be attributed to the change in stiffness of the members. Hence, the study concludes that the stiffer members tend to develop higher forces for constant differential settlement in frames.
\end{abstract}

Key Words: Differential settlement, Portal frame, Structural response, Frame forces, Storey, Bays

\section{INTRODUCTION}

The behavior of a building is greatly influenced by the settlement of the soil beneath its foundation. The compression of underlying soil beneath a structure because of increased load during and after the construction causes a vertically downward movement which is defined as settlement. If this settlement is uniform then it does not result in damage to the supported structure. However, when the settlement is non-uniform, it can largely damage the overlying structure. This unequal and non uniform settlement is called as differential settlement and occurs when the soil beneath the structure expands, contracts or shifts away.

Most of the times it is difficult to understand the exact cause of differential settlement but some of the common causes are expulsion of water from the soil mass, flooding, frost heave, inefficient drainage, water leaks from broken water lines, inappropriate design of foundation, the root systems of maturing trees, vibrations from nearby construction or poorly compacted fill soil.

Differential settlement can cause a significant tilt in the structure, making the occupants uncomfortable. Cracks in the foundation and interior walls, non-uniform settling of doors and windows, sinking of chimneys, bulging walls and sunken slabs are often considered as the adverse effects of differential settlement and can be devastating to a building. These effects are a result of increased axial force, shear force and bending moments in the structure. It is common to implement repair and maintenance measures to prevent or reduce the effects of differential settlement.

Due to the unpredictable soil and environmental conditions, differential settlement is often considered as inevitable. Hence, every engineer keeps in mind a certain degree of allowable settlement before designing the structure. The effects of differential settlement can be widely adverse and hence cannot be ignored.

\section{LITERATURE REVIEW}

Meyerhof [1] analyzed the building frames subjected to unequal settlement by studying the field observations and theoretical investigations. It was concluded that settlement of 1 inch to 2 inch is inevitable and does not usually harm the building. However, a settlement of 3 inch can seriously damage the building's superstructure due to the movement of supports. This is more prominent for structures provided with individual footings or flexible rafts. 
DeJong and Morgenstern [2] studied a three-dimensional frame structure to calculate the influence of settlement on the distribution of foundation loads. It was observed that small differential settlement was able to generate large reactions in the structural frame.

Man [3] studied the performance of RCC Frame influenced by differential settlement. The members associated with the settled columns were more seriously damaged. Also, the effect of differential settlement was more prominent for beam members as compared to column members.

D'Orazio et al [4] examined various steel tanks to determine the factors affecting the magnitude of tolerable differential settlement of tanks. A new method for determining the differential settlement was also recommended.

Dutta et al [5] studied the quantitative effect of soil-structure interaction on column axial forces of building frames with isolated footings. The change in column bending moments due to ratio of flexural stiffness of columns and beams, number of storeys and number of bays was analyzed. It was observed that the column moment in settlement condition was significantly higher as compared to no settlement condition. An approximate method of predicting the change in column moments by using the value of change in column axial force is determined.

Roy and dutta [6] analyzed a building frame with isolated footings to study the effect of differential settlement on frame members. It was found that differential settlement was responsible for redistribution of the column loads. The amount of these loads was dependent on the rigidity of the structure and the load-settlement characteristics of the soil. Also, the variation in amount of force due to soil-structure interaction can be minimized by the use of diagonal braces.

Agarwal and Hora [7] implemented the finite element method to study the non-linear interaction of a two-bay two storey plane building frame-soil system. It is observed that differential settlement causes the forces in the frame members to increase significantly.

Smit [8] analyzed the behavior of a 5-bay by 5-bay, 6 storey flat slab RC frame affected by differential settlement by using the linear-elastic finite element analyses. It was found that the structural behavior was dependent on the structure's overall relative bending stiffness. The axial load in the corner columns increases with the increase in relative bending stiffness. Also, a decrease in soil stiffness or structural stiffness caused the tilt in the structure to increase.

Le et al [9] studied the variation in differential settlement of a rigid strip foundation on an unsaturated soil caused due to rainfall. The magnitude of differential settlement varies with foundation load, variability statistics and rainfall duration. It is inferred that structures resting on unsaturated soils by means of rigid foundation can experience tilting and cracks due to settlement caused by rainfall infiltration.
Reddy and Rao [10] performed static vertical load tests on a model building frame supported by pile groups resting on sand to study the effects of rigidity of plinth on displacements, rotation, shear force and bending moments in the building frame. It was inferred that reducing the rigidity of the plinth beam can reduce the shear force and bending moment values considerably.

Sneha et al [11] estimated the vertical settlement and lateral displacement in buildings laid on variety of soils with different sub grade modulus reaction Ks. Buildings with small span of $3 \mathrm{~m}$ and large span of $6 \mathrm{~m}$ for both 5 storeys and 10 storeys were taken into consideration which were subjected to dead load, live load, earthquake load and wind loads. It is observed that with the increase in sub grade modulus reaction $\mathrm{Ks}$, there was an increase in the vertical settlement which can be compensated by increasing the size of the footing.

Lin et al [12] studied a 10-storey regular building with three-dimensional nonlinear finite element model. The responses of structure in terms of axial forces and vertical displacements of columns in each floor, bending moments and shear forces in beams were analyzed when the corner, edge and center columns were subjected to a settlement of $25 \mathrm{~mm}$. The deformation in structure is elastic for settlement up to $25 \mathrm{~mm}$ and the most critical case was that of the center column. It is also inferred that the adjacent beam of the settling column develops significant bending moment, the settling column develops tensile forces while the adjacent column develops compressive forces. The effect of differential settlement is limited to one span from the settling column.

Paixao et al [13] used the finite element method model to analyze the effect of differential settlement on a train-track system. A numerical model was presented which suggested that differential settlement was largely responsible for track degradation, affecting safety requirements and passenger comfort.

\section{PROPOSED WORK}

The present study investigates the forces developed in a concrete portal frame subjected to differential settlement of footing. The analysis is performed using STAAD Pro software. A support settlement load is given to the right most support in every case discussed in this paper. This is done so as to provide a settlement of $10 \mathrm{~mm}$ to one of the supports of the frame. The other support is kept as fixed support and hence a differential settlement of $10 \mathrm{~mm}$ is achieved in the frame. The results of the analyses of axial force, shear force and bending moment for different parameters of the frame are compared to study the effects of these parameters on differential settlement of the portal frame. The different parameters that are taken into consideration are length of beam, height of column, inertia of beam, inertia of column, number of storeys and number of bays. 


\section{MODELING}

Modeling is done using a structural analysis software i.e. STAAD Pro. A plain portal frame as shown in Fig 1 is taken as the reference frame for comparing the results of the analysis. The details of which are specified in table 1 .

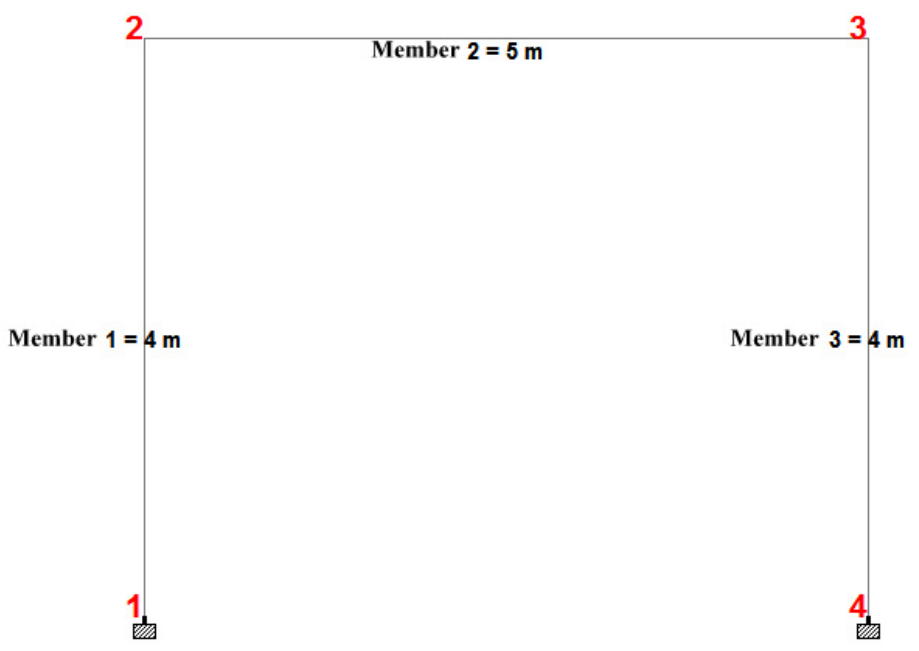

Fig -1: Reference frame showing joint and member numbering

Table -1: Details of reference frame

\begin{tabular}{|c|c|c|}
\hline $\begin{array}{l}\text { S. } \\
\text { No. }\end{array}$ & Description & Value/Type \\
\hline 1. & Structure type & Plain portal frame \\
\hline 2. & Material & Concrete \\
\hline 3. & $\begin{array}{l}\text { Modulus of elasticity of } \\
\text { concrete }\end{array}$ & $21.72 \mathrm{kN} / \mathrm{mm}^{2}$ \\
\hline 4. & Density of concrete & $2402.62 \mathrm{~kg} / \mathrm{m}^{3}$ \\
\hline 5. & No. of storeys & One \\
\hline 6. & No. of bays & One \\
\hline 7. & Length of beam & $5 \mathrm{~m}$ \\
\hline 8. & Height of column & $4 \mathrm{~m}$ \\
\hline 9. & Size of beam & $30 \mathrm{~cm} \times 50 \mathrm{~cm}$ \\
\hline 10. & Size of column & $40 \mathrm{~cm} \mathrm{x} 40 \mathrm{~cm}$ \\
\hline 11. & $\begin{array}{c}\text { Moment of inertia of } \\
\text { beam }\end{array}$ & $312500 \mathrm{~cm}^{4}$ \\
\hline 12. & $\begin{array}{l}\text { Moment of inertia of } \\
\text { column }\end{array}$ & $213333.3 \mathrm{~cm}^{4}$ \\
\hline 13. & Type of supports & Fixed \\
\hline 14. & Type of load & Settlement load \\
\hline 15. & Differential settlement & $10 \mathrm{~mm}$ \\
\hline
\end{tabular}

The different models used in this study apart from the reference frame model are as follows -

- To study the effect of changing beam length on frame forces, models with beam length $6 \mathrm{~m}$ and $4 \mathrm{~m}$ are used. All other parameters are same as that of the reference frame.

- To study the effect of changing column height, models with column height $5 \mathrm{~m}$ and $3 \mathrm{~m}$ are used. All other parameters are same as that of the reference frame.

- To study the effect of changing beam inertia, models with beam size $30 \mathrm{~cm}$ x $60 \mathrm{~cm}$ and $30 \mathrm{~cm}$ x $40 \mathrm{~cm}$ are used. The moment of inertia of beam in the two models is $540000 \mathrm{~cm}^{4}$ and $160000 \mathrm{~cm}^{4}$ respectively. All other parameters are same as that of the reference frame.

- To study the effect of changing column inertia, models with column size $50 \mathrm{~cm}$ x $50 \mathrm{~cm}$ and $40 \mathrm{~cm}$ x $40 \mathrm{~cm}$ are used. The moment of inertia of columns in the two models is $520833.3 \mathrm{~cm}^{4}$ and $67500 \mathrm{~cm}^{4}$ respectively. All other parameters are same as that of the reference frame.

- To study the effect of number of storeys on frame forces, two models of two and three storeys are used. All other parameters are same as that of the reference frame.

- To study the effect of number of bays on frame forces, two models of two and three bays are used. All other parameters are same as that of the reference frame.

\section{RESULTS AND DISCUSSIONS}

In the following section, the effect of various parameters on frame forces is discussed for a portal frame subjected to differential settlement of $10 \mathrm{~mm}$. The increase or decrease in axial force, shear force and bending moment is observed for changing the beam length, column height, beam inertia, column inertia, number of storeys and number of bays.

\subsection{Effect of Beam Length on frame forces}

From table 2, it is observed that when the beam length is increased to 1.20 times of the reference beam length, the axial force in the column and the shear force in the beam is reduced to 0.68 times whereas the bending moment in the frame is reduced to 0.81 times. Similarly when the beam length is decreased to 0.80 times of the reference beam length, the axial force in the column and the shear force in the beam is increased to 1.59 times where as the bending moment in the frame is increased to 1.28 times. Hence, the smaller the span of beam, larger will be the forces developed due to differential settlement. The axial force, shear force and bending moment diagrams for different lengths of beam are shown in Fig 2. 

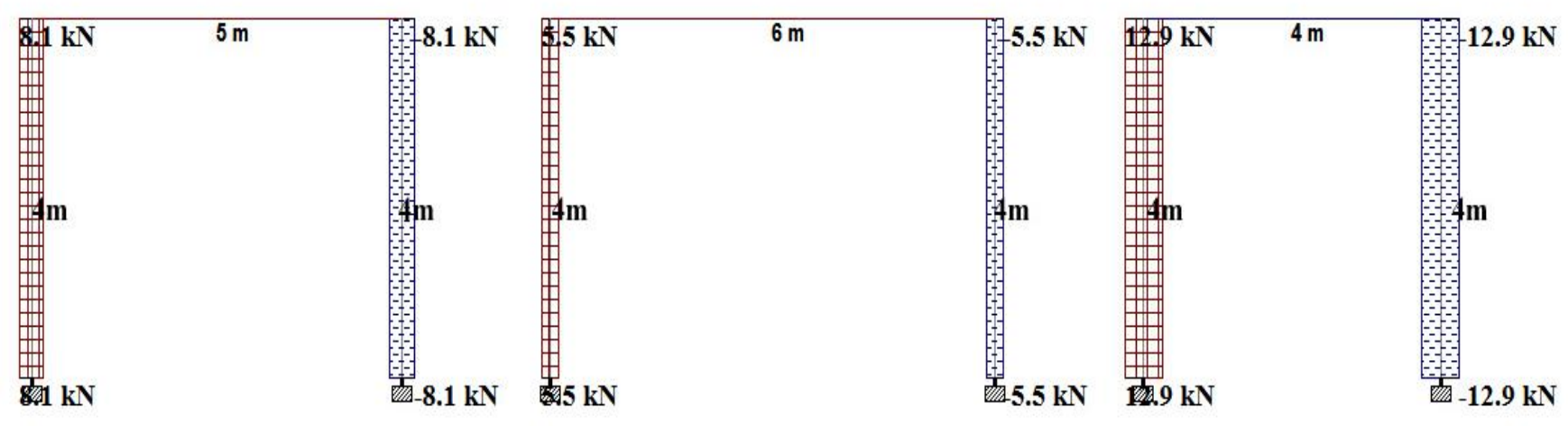

Reference beam length $=5 \mathrm{~m}$

Increased beam length $=6 \mathrm{~m}$

Decreased beam length $=4 \mathrm{~m}$

(a) Axial force diagram

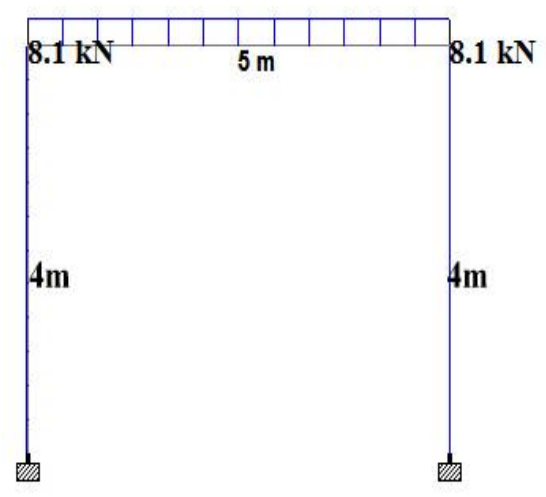

Reference beam length $=5 \mathrm{~m}$

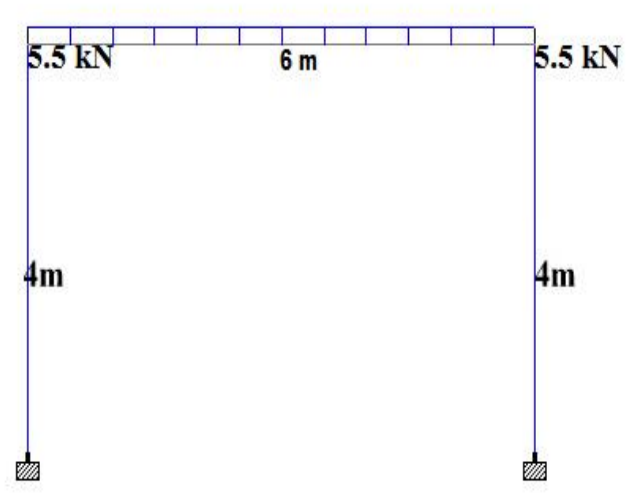

Increased beam length $=6 \mathrm{~m}$

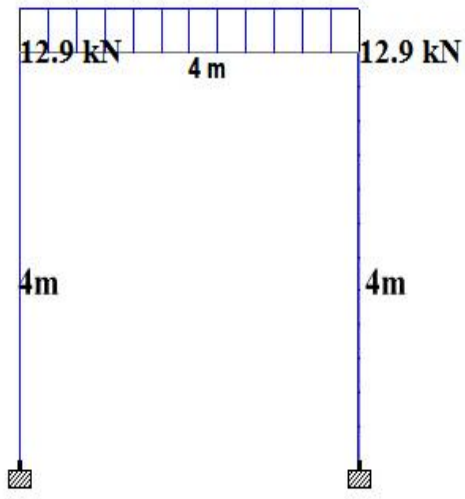

Decreased beam length $=4 \mathrm{~m}$

(b) Shear force diagram

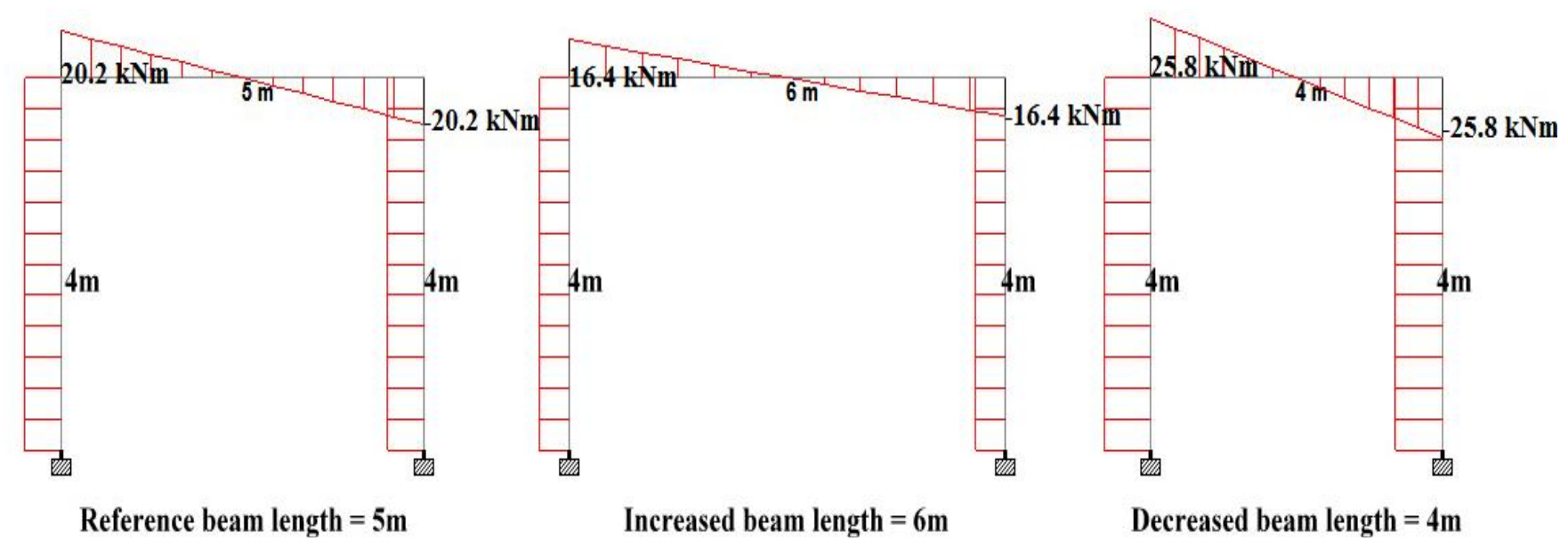

(c) Bending moment diagram

Fig -2: Variation of forces in frame for different beam lengths 


\subsection{Effect Of Column Height On Frame Forces}

From table 3 , it is observed that when the column height is increased to 1.25 times of the reference column height, the axial force in the column and the shear force in the beam is reduced to 0.81 times and the bending moment is reduced to 0.82 times when compared to the reference frame. Also, when the column height is reduced to 0.75 times of the reference column height, the axial force in the column and the shear force in the beam is increased to 1.27 times and the bending moment is increased to 1.28. Hence, the smaller the height of column, larger will be the forces developed due to constant differential settlement. The axial force, shear force and bending moment diagrams for different heights of column are shown in Fig 3.
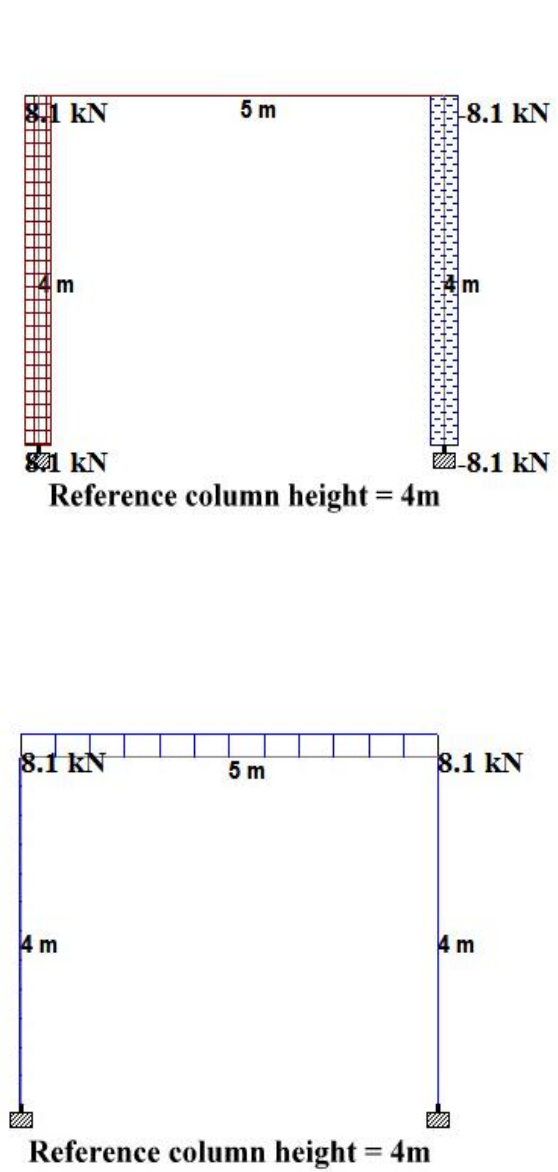

Reference column height $=4 \mathrm{~m}$

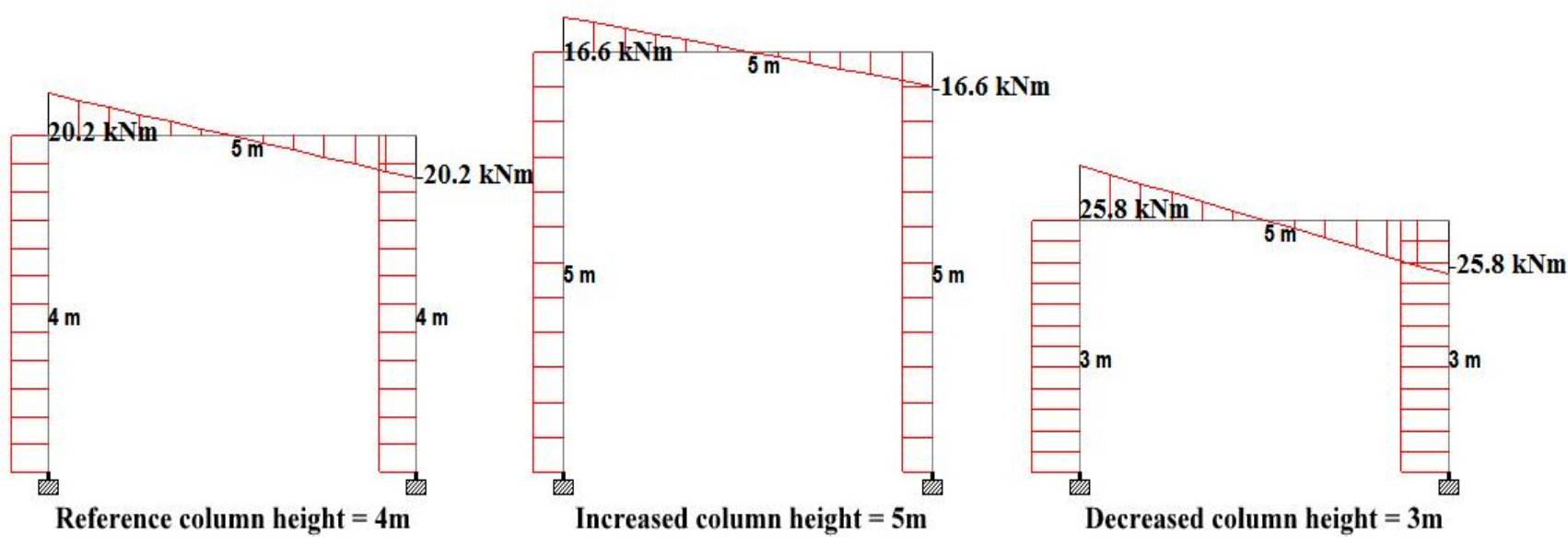

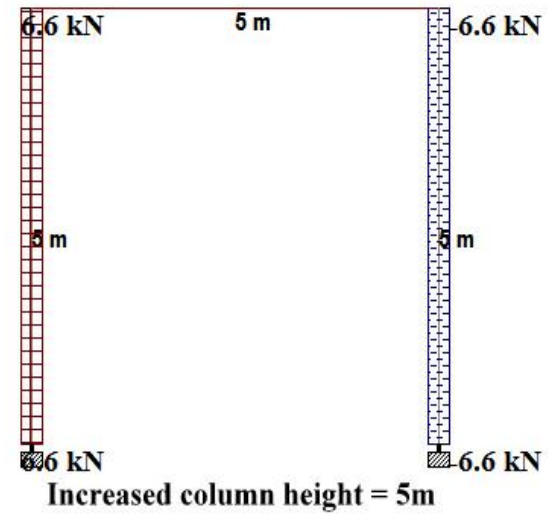

(a) Axial force diagram

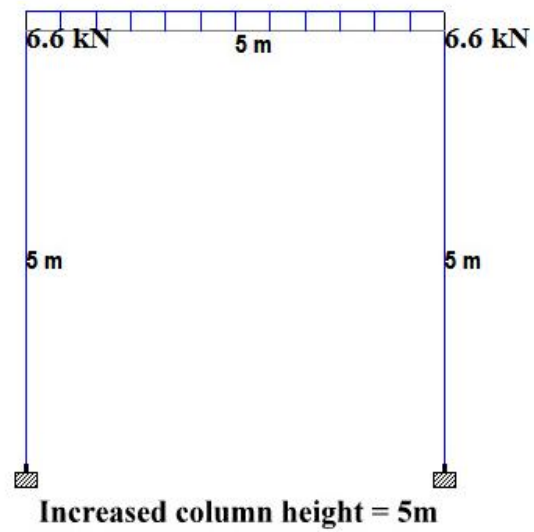

(b) Shear force diagram
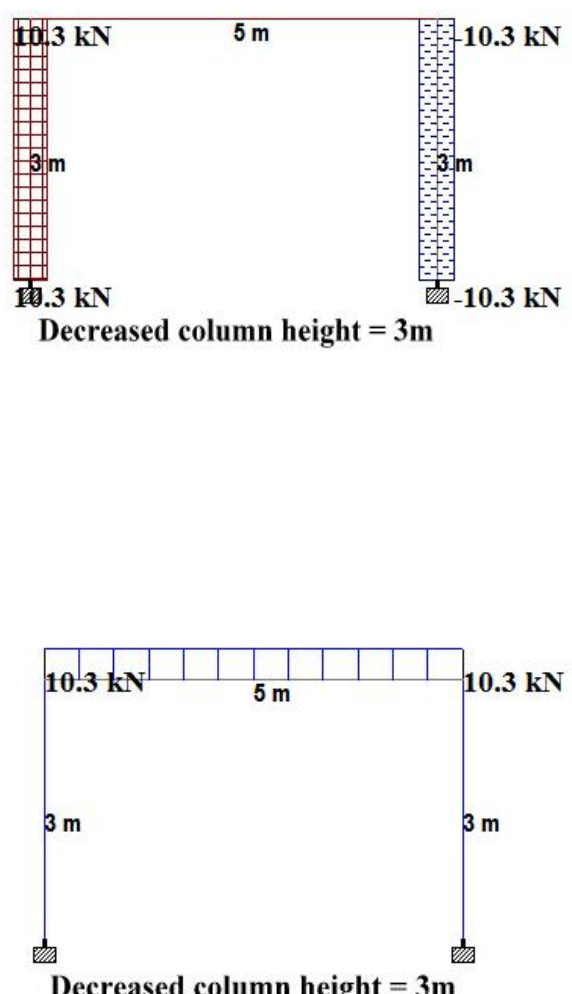

Decreased column height $=3 \mathrm{~m}$

(c) Bending moment diagram

Fig -3: Variation of forces in frame for different column heights 
Table -2: Effect of variation of beam length on frame forces developed due to differential settlement

\begin{tabular}{|c|c|c|c|c|c|c|c|c|c|c|c|c|c|c|c|c|}
\hline \multirow{4}{*}{ 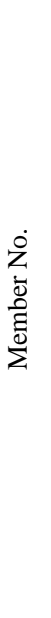 } & \multirow{4}{*}{$\stackrel{0}{0}$} & \multicolumn{9}{|c|}{ Frame forces for different lengths of beam } & \multicolumn{6}{|c|}{ Comparison of Analyses } \\
\hline & & Refere & beam & ngth $5 \mathrm{~m}$ & Incr & $\begin{array}{c}\text { ed bea } \\
6 \mathrm{~m}\end{array}$ & length & Decre & $\begin{array}{l}\text { ed bean } \\
4 \mathrm{~m}\end{array}$ & length & \multicolumn{3}{|c|}{$\begin{array}{l}\text { Effect of increase in length } \\
\qquad(6 \mathrm{~m} / 5 \mathrm{~m}=1.20)\end{array}$} & \multicolumn{3}{|c|}{$\begin{array}{l}\text { Effect of decrease in length } \\
\qquad(4 \mathrm{~m} / 5 \mathrm{~m}=0.80)\end{array}$} \\
\hline & & 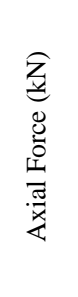 & 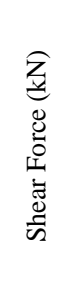 & 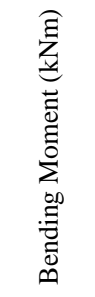 & 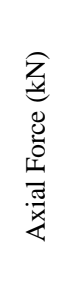 & 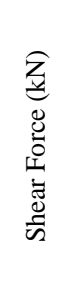 & 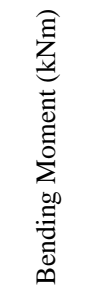 & 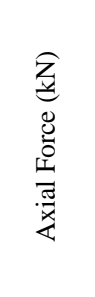 & 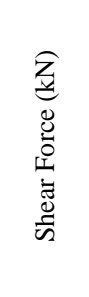 & 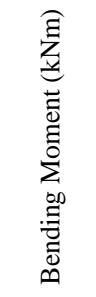 & 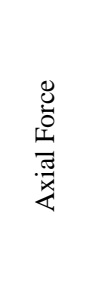 & 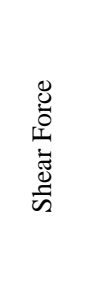 & $\begin{array}{l}\overrightarrow{0} \\
\sum_{0}^{0} \\
\sum_{\infty}^{0} \\
\stackrel{0}{0} \\
\stackrel{0}{0} \\
\infty\end{array}$ & 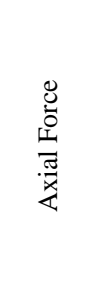 & 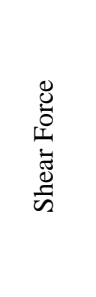 & 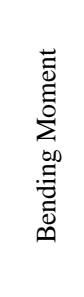 \\
\hline & & (1) & (2) & (3) & (4) & $(5)$ & (6) & (7) & (8) & (9) & $\begin{array}{l}\text { Ratio } \\
(4) /(1)\end{array}$ & $\begin{array}{l}\text { Ratio } \\
(5) /(2)\end{array}$ & $\begin{array}{l}\text { Ratio } \\
(6) /(3)\end{array}$ & $\begin{array}{l}\text { Ratio } \\
(7) /(1)\end{array}$ & $\begin{array}{l}\text { Ratio } \\
(8) /(2)\end{array}$ & $\begin{array}{l}\text { Ratio } \\
(9) /(3)\end{array}$ \\
\hline \multirow{2}{*}{1} & 1 & 8.10 & 0.00 & 20.20 & 5.50 & 0.00 & 16.40 & 12.90 & 0.00 & 25.80 & 0.68 & - & 0.81 & 1.59 & - & 1.28 \\
\hline & 2 & -8.10 & 0.00 & -20.20 & -5.50 & 0.00 & -16.40 & -12.90 & 0.00 & -25.80 & 0.68 & - & 0.81 & 1.59 & - & 1.28 \\
\hline \multirow{2}{*}{2} & 2 & 0.00 & 8.10 & 20.20 & 0.00 & 5.50 & 16.40 & 0.00 & 12.90 & 25.80 & - & 0.68 & 0.81 & - & 1.59 & 1.28 \\
\hline & 3 & 0.00 & -8.10 & 20.20 & 0.00 & -5.50 & 16.40 & 0.00 & -12.90 & 25.80 & - & 0.68 & 0.81 & - & 1.59 & 1.28 \\
\hline \multirow{2}{*}{3} & 3 & -8.10 & 0.00 & -20.20 & -5.50 & 0.00 & -16.40 & -12.90 & 0.00 & -25.80 & 0.68 & - & 0.81 & 1.59 & - & 1.28 \\
\hline & 4 & 8.10 & 0.00 & 20.20 & 5.50 & 0.00 & 16.40 & 12.90 & 0.00 & 25.80 & 0.68 & - & 0.81 & 1.59 & - & 1.28 \\
\hline
\end{tabular}

Table -3: Effect of variation of column height on frame forces developed due to differential settlement

\begin{tabular}{|c|c|c|c|c|c|c|c|c|c|c|c|c|c|c|c|c|}
\hline \multirow{4}{*}{ 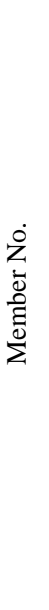 } & \multirow{4}{*}{$\begin{array}{l}\stackrel{0}{0} \\
\stackrel{2}{z}\end{array}$} & \multicolumn{9}{|c|}{ Frame forces for different height of columns } & \multicolumn{6}{|c|}{ Comparison of Analyses } \\
\hline & & Refer & $\begin{array}{l}\text { ce colu } \\
4 \mathrm{~m}\end{array}$ & $n$ height & Increa & $\begin{array}{c}\mathrm{d} \text { colu } \\
5 \mathrm{~m}\end{array}$ & height & Decre & $\begin{array}{l}\text { ed colum } \\
3 \mathrm{~m}\end{array}$ & height & \multicolumn{3}{|c|}{$\begin{array}{l}\text { Effect of increase in height } \\
\qquad(5 \mathrm{~m} / 4 \mathrm{~m}=1.25)\end{array}$} & \multicolumn{3}{|c|}{$\begin{array}{l}\text { Effect of decrease in height } \\
\qquad(3 \mathrm{~m} / 4 \mathrm{~m}=0.75)\end{array}$} \\
\hline & & 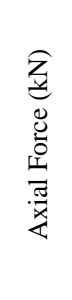 & 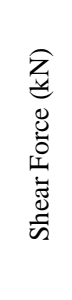 & 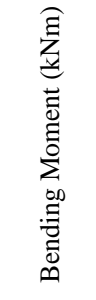 & 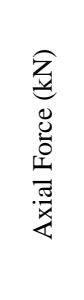 & 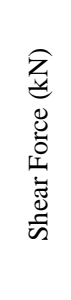 & 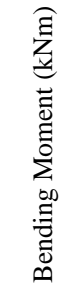 & 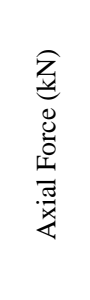 & 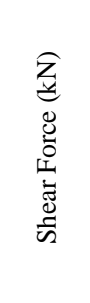 & 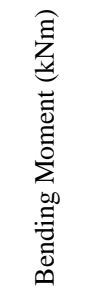 & 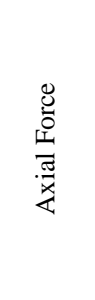 & 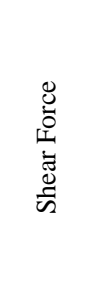 & 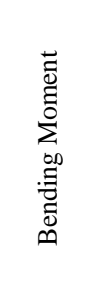 & 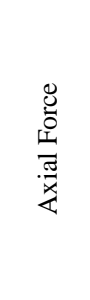 & 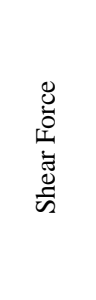 & 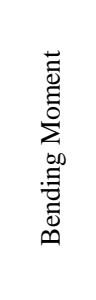 \\
\hline & & (1) & (2) & (3) & (4) & (5) & (6) & (7) & (8) & (9) & $\begin{array}{l}\text { Ratio } \\
(4) /(1)\end{array}$ & $\begin{array}{l}\text { Ratio } \\
(5) /(2)\end{array}$ & $\begin{array}{l}\text { Ratio } \\
(6) /(3)\end{array}$ & $\begin{array}{l}\text { Ratio } \\
(7) /(1)\end{array}$ & $\begin{array}{l}\text { Ratio } \\
(8) /(2)\end{array}$ & $\begin{array}{l}\text { Ratio } \\
(9) /(3)\end{array}$ \\
\hline \multirow{2}{*}{1} & 1 & 8.10 & 0.00 & 20.20 & 6.60 & 0.00 & 16.60 & 10.30 & 0.00 & 25.80 & 0.81 & - & 0.82 & 1.27 & - & 1.28 \\
\hline & 2 & -8.10 & 0.00 & -20.20 & -6.60 & 0.00 & -16.60 & -10.30 & 0.00 & -25.80 & 0.81 & - & 0.82 & 1.27 & - & 1.28 \\
\hline \multirow{2}{*}{2} & 2 & 0.00 & 8.10 & 20.20 & 0.00 & 6.60 & 16.60 & 0.00 & 10.30 & 25.80 & - & 0.81 & 0.82 & - & 1.27 & 1.28 \\
\hline & 3 & 0.00 & -8.10 & 20.20 & 0.00 & -6.60 & 16.60 & 0.00 & -10.30 & 25.80 & - & 0.81 & 0.82 & - & 1.27 & 1.28 \\
\hline \multirow{2}{*}{3} & 3 & -8.10 & 0.00 & -20.20 & -6.60 & 0.00 & -16.60 & -10.30 & 0.00 & -25.80 & 0.81 & - & 0.82 & 1.27 & - & 1.28 \\
\hline & 4 & 8.10 & 0.00 & 20.20 & 6.60 & 0.00 & 16.60 & 10.30 & 0.00 & 25.80 & 0.81 & - & 0.82 & 1.27 & - & 1.28 \\
\hline
\end{tabular}




\subsection{Effect Of Moment Of Inertia Of Beam On}

\section{Frame Forces}

From table 4, it is observed that when the beam inertia is increased to 1.73 times of the reference beam inertia, the axial force in the column, the shear force in the beam and the bending moment in the frame is increased to 1.05 times. Similarly when the beam inertia is decreased to 0.51 times of the reference beam inertia, the axial force in the column, the shear force in the beam and the bending moment in the frame is reduced to 0.89 times. Therefore, on increasing the moment of inertia of beam, the forces developed due to constant differential settlement will also increase. The axial force, shear force and bending moment diagrams for different inertias of beam are shown in Fig 4.

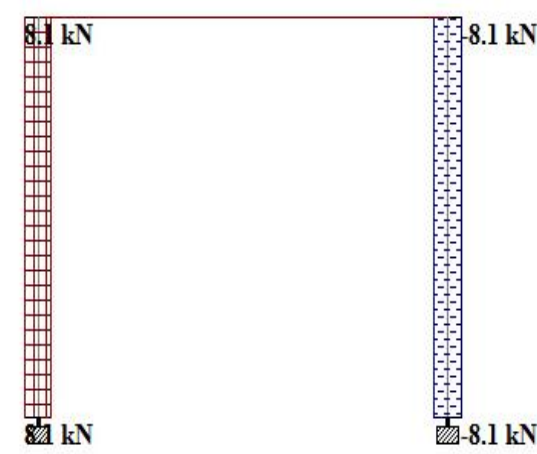

Reference beam inertia $=312500 \mathrm{~cm}^{4}$ $($ Size $=30 \mathrm{~cm} \times 50 \mathrm{~cm})$

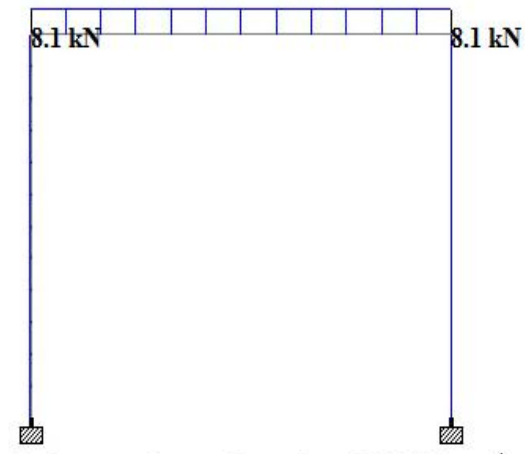

Reference beam inertia $=312500 \mathrm{~cm}^{4}$ $($ Size $=30 \mathrm{~cm} \times 50 \mathrm{~cm})$

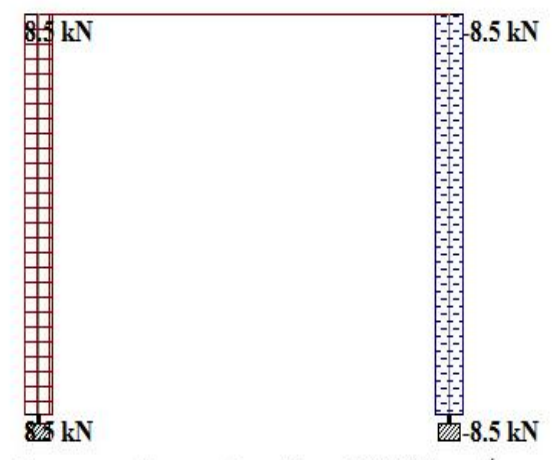

Increased beam inertia $=540000 \mathrm{~cm}^{4}$ $(\mathrm{Size}=30 \mathrm{~cm} \times 60 \mathrm{~cm})$

(a) Axial force diagram

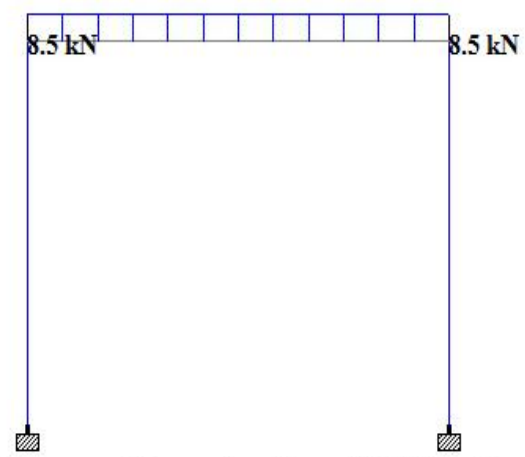

Increased beam inertia $=540000 \mathrm{~cm}^{4}$ $(\mathrm{Size}=30 \mathrm{~cm} \times 60 \mathrm{~cm})$

(b) Shear force diagram

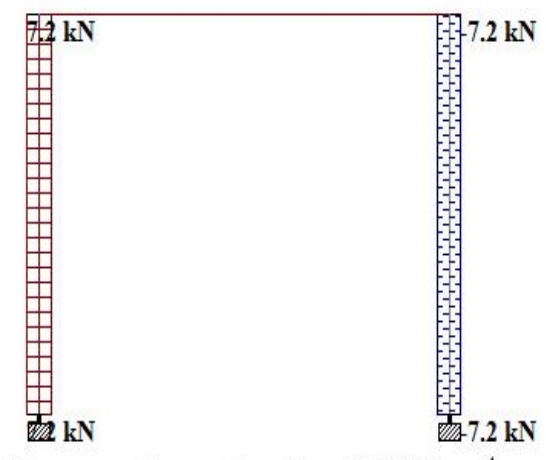

Decreased beam inertia $=160000 \mathrm{~cm}^{4}$ $($ Size $=30 \mathrm{~cm} \times 40 \mathrm{~cm})$

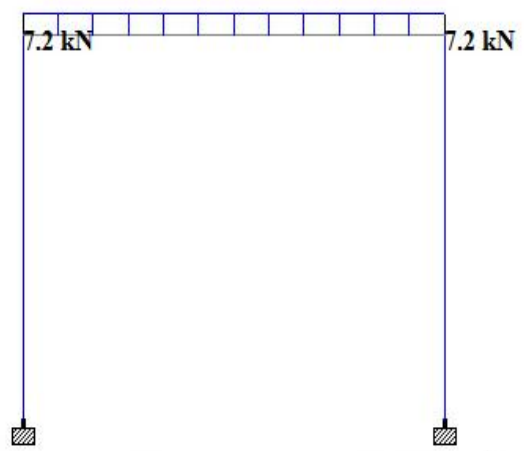

Decreased beam inertia $=160000 \mathrm{~cm}^{4}$ $($ Size $=30 \mathrm{~cm} \times 40 \mathrm{~cm})$

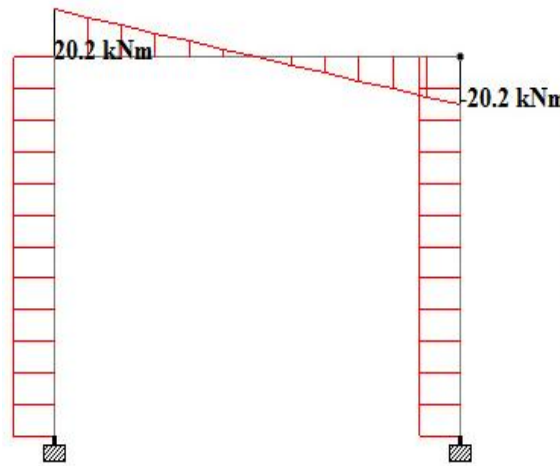

Reference beam inertia $=312500 \mathrm{~cm}^{4}$ $($ Size $=30 \mathrm{~cm} \times 50 \mathrm{~cm})$

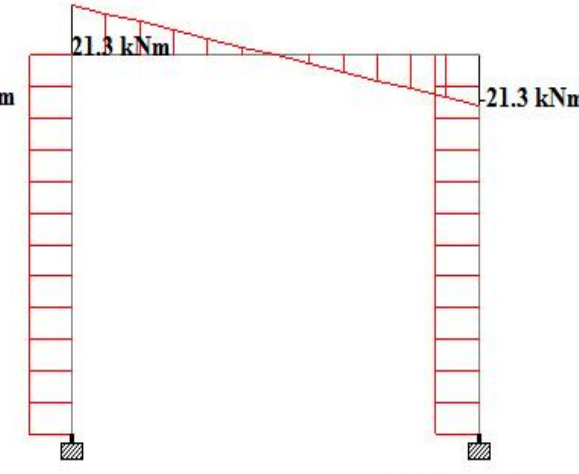

Increased beam inertia $=540000 \mathrm{~cm}^{4}$ $($ Size $=30 \mathrm{~cm} \times 60 \mathrm{~cm})$

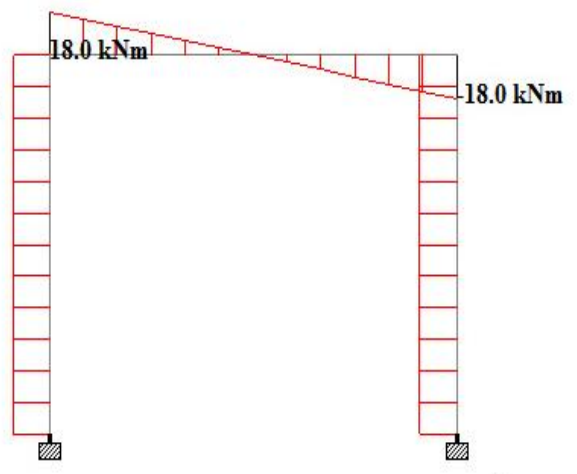

Decreased beam inertia $=160000 \mathrm{~cm}^{4}$ $(\mathrm{Size}=30 \mathrm{~cm} \times 40 \mathrm{~cm})$

(c) Bending moment diagram

Fig -4: Variation of forces in frame for different beam inertia 


\subsection{Effect Of Moment Of Inertia Of Columns On}

\section{Frame Forces}

From table 5, it is observed that when the column inertia is increased to 2.44 times of the reference column inertia, the axial force in the column and the shear force in the beam is increased to 2.05 times and the bending moment in the frame is increased to 2.06 times as compared to that of reference frame. Similarly when the column inertia is decreased to 0.32 times of the reference column inertia, the axial force in the column, the shear force in the beam and the bending moment in the frame is reduced to 0.35 times. Therefore, on increasing the moment of inertia of column, the forces developed due to constant differential settlement will also increase. The axial force, shear force and bending moment diagrams for different inertias of column are shown in Fig 5.

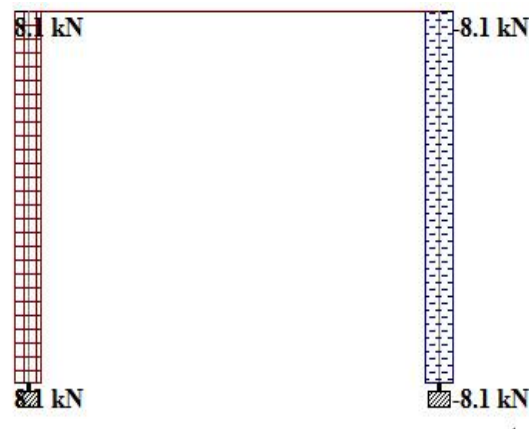

Reference column inertia $=213333.3 \mathrm{~cm}^{4}$ $($ Size $=40 \mathrm{~cm} \times 40 \mathrm{~cm})$

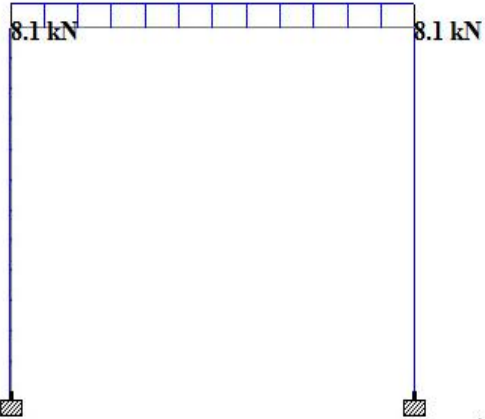

Reference column inertia $=213333.3 \mathrm{~cm}^{4}$ $($ Size $=40 \mathrm{~cm} \times 40 \mathrm{~cm})$

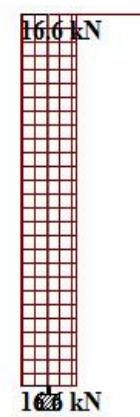

Increased column inertia $=520833.3 \mathrm{~cm}^{4}$ $($ Size $=50 \mathrm{~cm} \times 50 \mathrm{~cm})$
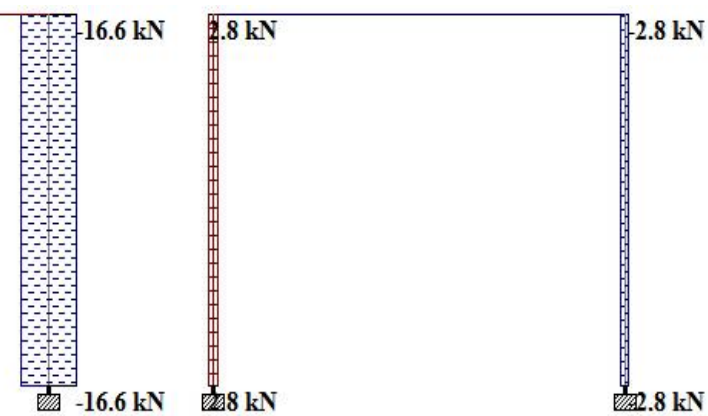

Decreased column inertia $=67500 \mathrm{~cm}^{4}$ $(\mathrm{Size}=30 \mathrm{~cm} \times 30 \mathrm{~cm})$

(a) Axial force diagram

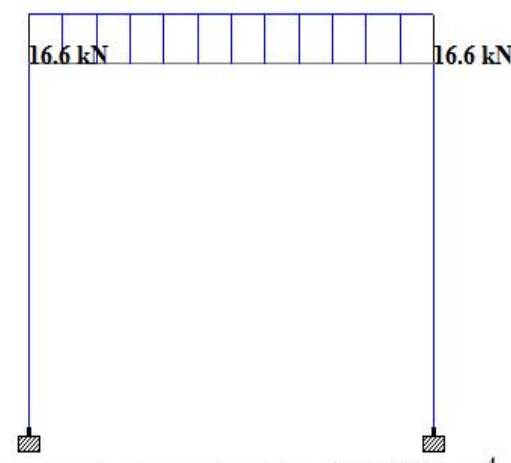

Increased column inertia $=520833.3 \mathrm{~cm}^{4}$ $($ Size $=50 \mathrm{~cm} \times 50 \mathrm{~cm})$

(b) Shear force diagram

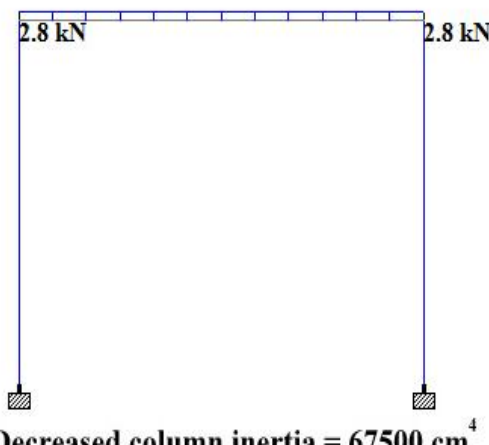

Decreased column inertia $=67500 \mathrm{~cm}^{4}$ $($ Size $=30 \mathrm{~cm} \times 30 \mathrm{~cm})$

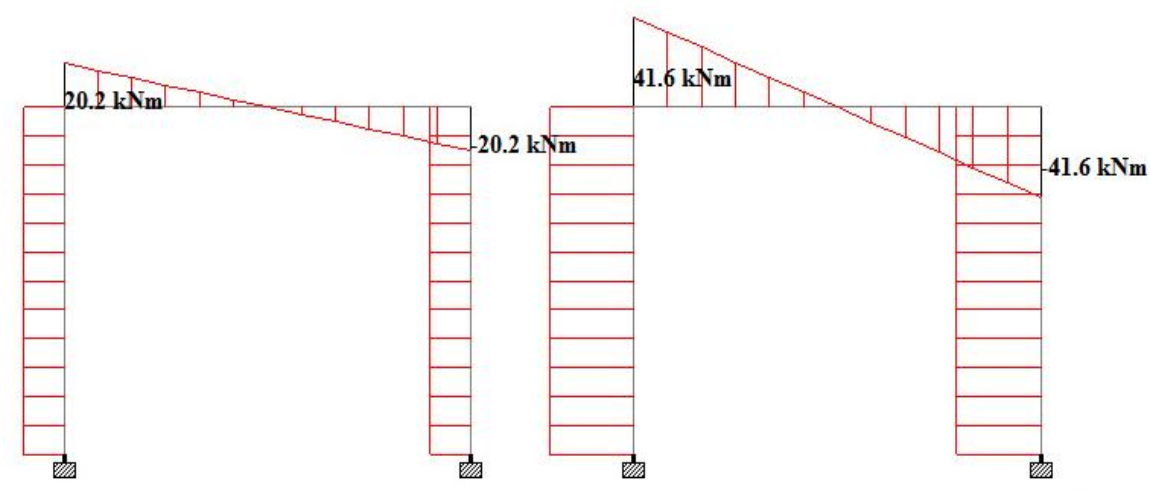

Reference column inertia $=\mathbf{2 1 3 3 3 3 . 3} \mathrm{cm}^{4} \quad$ Increased column inertia $=\mathbf{5 2 0 8 3 3 . 3} \mathrm{cm}^{4}$ $($ Size $=40 \mathrm{~cm} \times 40 \mathrm{~cm})$
$(S i z e=50 \mathrm{~cm} \times 50 \mathrm{~cm})$

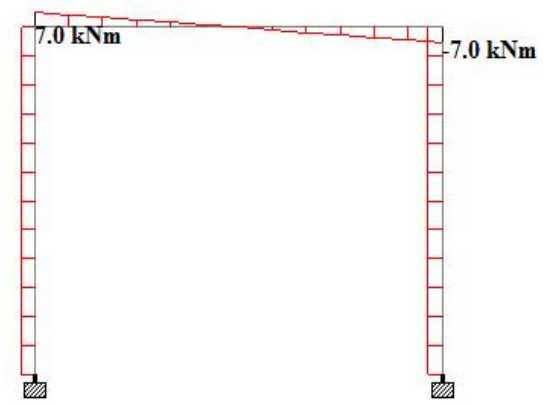

Decreased column inertia $=67500 \mathrm{~cm}^{4}$ $($ Size $=30 \mathrm{~cm} \times 30 \mathrm{~cm})$

(c) Bending moment diagram

Fig -5: Variation of forces in frame for different column inertia 
Table -4: Effect of variation of moment of inertia of beam on frame forces developed due to differential settlement

\begin{tabular}{|c|c|c|c|c|c|c|c|c|c|c|c|c|c|c|c|c|}
\hline \multirow{4}{*}{ 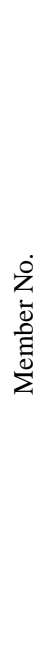 } & \multirow{4}{*}{$\frac{\mathbb{0}}{0}$} & \multicolumn{9}{|c|}{ Frame forces for different inertia of beams } & \multicolumn{6}{|c|}{ Comparison of Analyses } \\
\hline & & \multicolumn{3}{|c|}{$\begin{array}{c}\text { Reference beam inertia } \\
\quad 312500 \mathrm{~cm}^{4} \\
(\text { Size }=30 \mathrm{~cm} \times 50 \mathrm{~cm})\end{array}$} & \multicolumn{3}{|c|}{$\begin{array}{l}\text { Increased beam inertia } \\
\quad 540000 \mathrm{~cm}^{4} \\
(\text { Size }=30 \mathrm{~cm} \times 60 \mathrm{~cm})\end{array}$} & \multicolumn{3}{|c|}{$\begin{array}{c}\text { Decreased beam inertia } \\
160000 \mathrm{~cm}^{4} \\
(\text { Size }=30 \mathrm{~cm} \times 40 \mathrm{~cm})\end{array}$} & \multicolumn{3}{|c|}{$\begin{array}{l}\text { Effect of increase in inertia } \\
(540000 / 312500=1.73)\end{array}$} & \multicolumn{3}{|c|}{$\begin{array}{l}\text { Effect of decrease in inertia } \\
(160000 / 312500=0.51)\end{array}$} \\
\hline & & 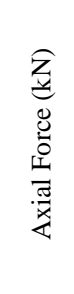 & 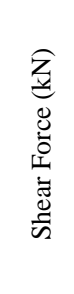 & 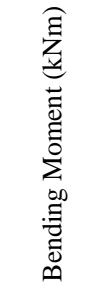 & 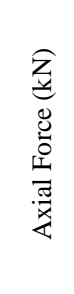 & 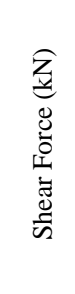 & 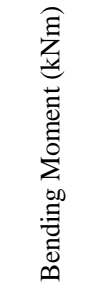 & 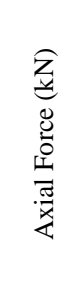 & 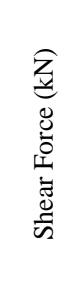 & 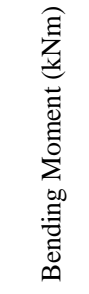 & 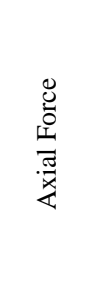 & 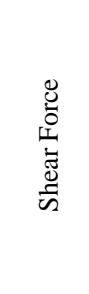 & 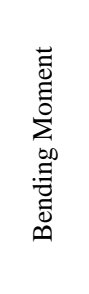 & 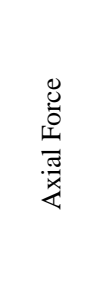 & 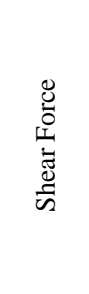 & 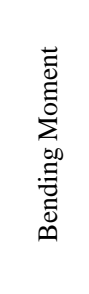 \\
\hline & & (1) & (2) & (3) & (4) & (5) & (6) & (7) & (8) & (9) & $\begin{array}{l}\text { Ratio } \\
(4) /(1)\end{array}$ & $\begin{array}{l}\text { Ratio } \\
(5) /(2)\end{array}$ & $\begin{array}{l}\text { Ratio } \\
(6) /(3)\end{array}$ & $\begin{array}{l}\text { Ratio } \\
(7) /(1)\end{array}$ & $\begin{array}{l}\text { Ratio } \\
(8) /(2)\end{array}$ & $\begin{array}{l}\text { Ratio } \\
(9) /(3)\end{array}$ \\
\hline \multirow{2}{*}{1} & 1 & 8.10 & 0.00 & 20.20 & 8.50 & 0.00 & 21.30 & 7.20 & 0.00 & 18.00 & 1.05 & - & 1.05 & 0.89 & - & 0.89 \\
\hline & 2 & -8.10 & 0.00 & -20.20 & -8.50 & 0.00 & -21.30 & -7.20 & 0.00 & -18.00 & 1.05 & - & 1.05 & 0.89 & - & 0.89 \\
\hline \multirow{2}{*}{2} & 2 & 0.00 & 8.10 & 20.20 & 0.00 & 8.50 & 21.30 & 0.00 & 7.20 & 18.00 & - & 1.05 & 1.05 & - & 0.89 & 0.89 \\
\hline & 3 & 0.00 & -8.10 & 20.20 & 0.00 & -8.50 & 21.30 & 0.00 & -7.20 & 18.00 & - & 1.05 & 1.05 & - & 0.89 & 0.89 \\
\hline \multirow{2}{*}{3} & 3 & -8.10 & 0.00 & -20.20 & -8.50 & 0.00 & -21.30 & -7.20 & 0.00 & -18.00 & 1.05 & - & 1.05 & 0.89 & - & 0.89 \\
\hline & 4 & 8.10 & 0.00 & 20.20 & 8.50 & 0.00 & 21.30 & 7.20 & 0.00 & 18.00 & 1.05 & - & 1.05 & 0.89 & - & 0.89 \\
\hline
\end{tabular}

Table -5: Effect of variation of moment of inertia of column on frame forces developed due to differential settlement

\begin{tabular}{|c|c|c|c|c|c|c|c|c|c|c|c|c|c|c|c|c|}
\hline \multirow{4}{*}{ 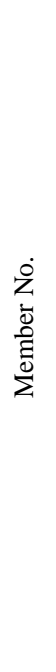 } & \multirow{4}{*}{$\frac{ \pm}{0}$} & \multicolumn{9}{|c|}{ Frame forces for different inertia of columns } & \multicolumn{6}{|c|}{ Comparison of Analyses } \\
\hline & & \multicolumn{3}{|c|}{$\begin{array}{c}\text { Reference column } \\
\text { inertia } \\
213333.3 \mathrm{~cm}^{4} \\
(\text { Size }=40 \mathrm{~cm} \times 40 \mathrm{~cm})\end{array}$} & \multicolumn{3}{|c|}{$\begin{array}{c}\text { Increased column inertia } \\
520833.3 \mathrm{~cm}^{4} \\
(\text { Size }=50 \mathrm{~cm} \mathrm{x} 50 \mathrm{~cm})\end{array}$} & \multicolumn{3}{|c|}{$\begin{array}{c}\text { Decreased column } \\
\text { inertia } \\
67500 \mathrm{~cm}^{4} \\
\text { (Size }=30 \mathrm{~cm} \times 30 \mathrm{~cm})\end{array}$} & \multicolumn{3}{|c|}{$\begin{array}{l}\text { Effect of increase in inertia } \\
(520833.3 / 213333.3=2.44)\end{array}$} & \multicolumn{3}{|c|}{$\begin{array}{l}\text { Effect of decrease in inertia } \\
(67500 / 213333.3=0.32)\end{array}$} \\
\hline & & 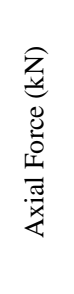 & 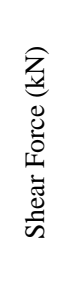 & 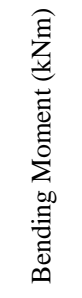 & 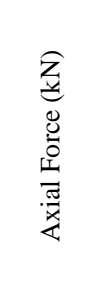 & 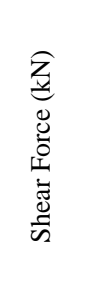 & 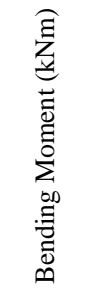 & 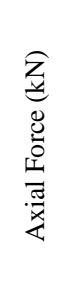 & 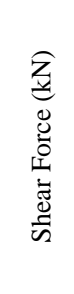 & 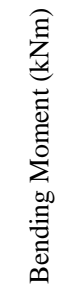 & 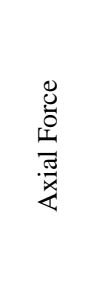 & 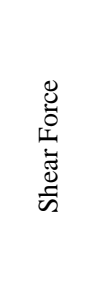 & 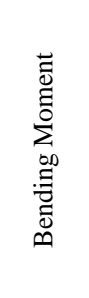 & 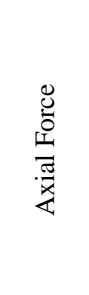 & 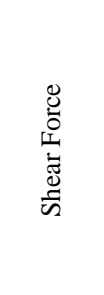 & 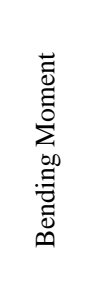 \\
\hline & & (1) & (2) & (3) & (4) & (5) & (6) & (7) & (8) & (9) & $\begin{array}{l}\text { Ratio } \\
(4) /(1)\end{array}$ & $\begin{array}{l}\text { Ratio } \\
(5) /(2)\end{array}$ & $\begin{array}{l}\text { Ratio } \\
(6) /(3)\end{array}$ & $\begin{array}{l}\text { Ratio } \\
(7) /(1)\end{array}$ & $\begin{array}{l}\text { Ratio } \\
(8) /(2)\end{array}$ & $\begin{array}{l}\text { Ratio } \\
(9) /(3)\end{array}$ \\
\hline \multirow{2}{*}{1} & 1 & 8.10 & 0.00 & 20.20 & 16.60 & 0.00 & 41.60 & 2.80 & 0.00 & 7.00 & 2.05 & - & 2.06 & 0.35 & - & 0.35 \\
\hline & 2 & -8.10 & 0.00 & -20.20 & -16.60 & 0.00 & -41.60 & -2.80 & 0.00 & -7.00 & 2.05 & - & 2.06 & 0.35 & - & 0.35 \\
\hline \multirow{2}{*}{2} & 2 & 0.00 & 8.10 & 20.20 & 0.00 & 16.60 & 41.60 & 0.00 & 2.80 & 7.00 & - & 2.05 & 2.06 & - & 0.35 & 0.35 \\
\hline & 3 & 0.00 & -8.10 & 20.20 & 0.00 & -16.60 & 41.60 & 0.00 & -2.80 & 7.00 & - & 2.05 & 2.06 & - & 0.35 & 0.35 \\
\hline \multirow{2}{*}{3} & 3 & -8.10 & 0.00 & -20.20 & -16.60 & 0.00 & -41.60 & -2.80 & 0.00 & -7.00 & 2.05 & - & 2.06 & 0.35 & - & 0.35 \\
\hline & 4 & 8.10 & 0.00 & 20.20 & 16.60 & 0.00 & 41.60 & 2.80 & 0.00 & 7.00 & 2.05 & - & 2.06 & 0.35 & - & 0.35 \\
\hline
\end{tabular}




\subsection{Effect Of Number Of Storeys On Frame Forces}

To study the effect of number of storeys on frame forces, three models of one, two and three storey are taken into consideration. The variation of axial force, shear force and bending moment with number of storey is shown in Fig 6. It is found that the effect of differential settlement on frame forces is significant for ground storey only. As the number of storey increases, this effect diminishes drastically.

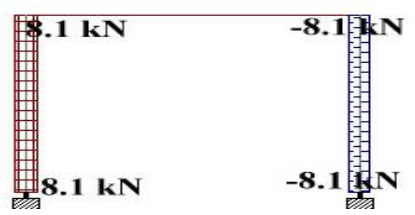

One storey

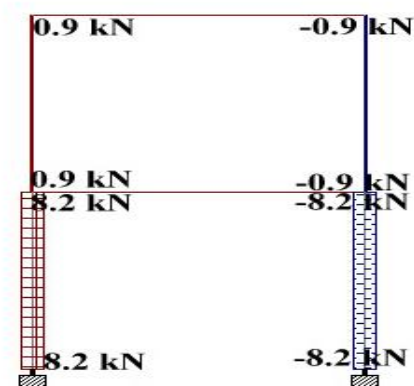

Two storey

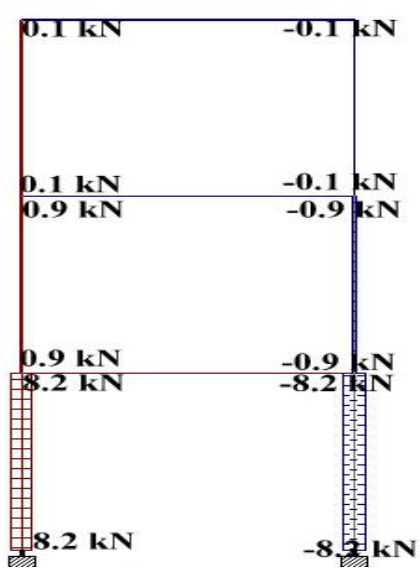

Three storey

(a) Axial force diagram

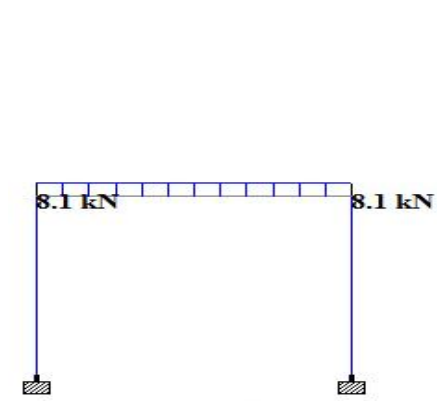

One storey

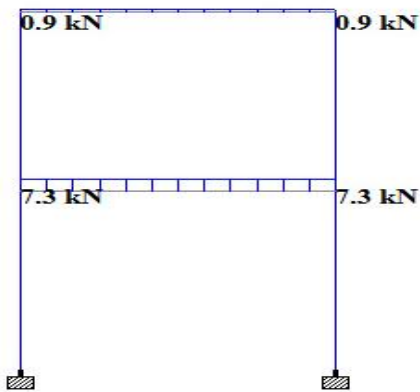

Two storey

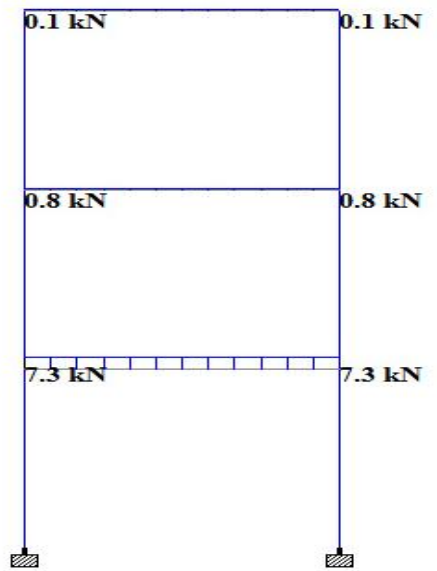

Three storey

(b) Shear force diagram

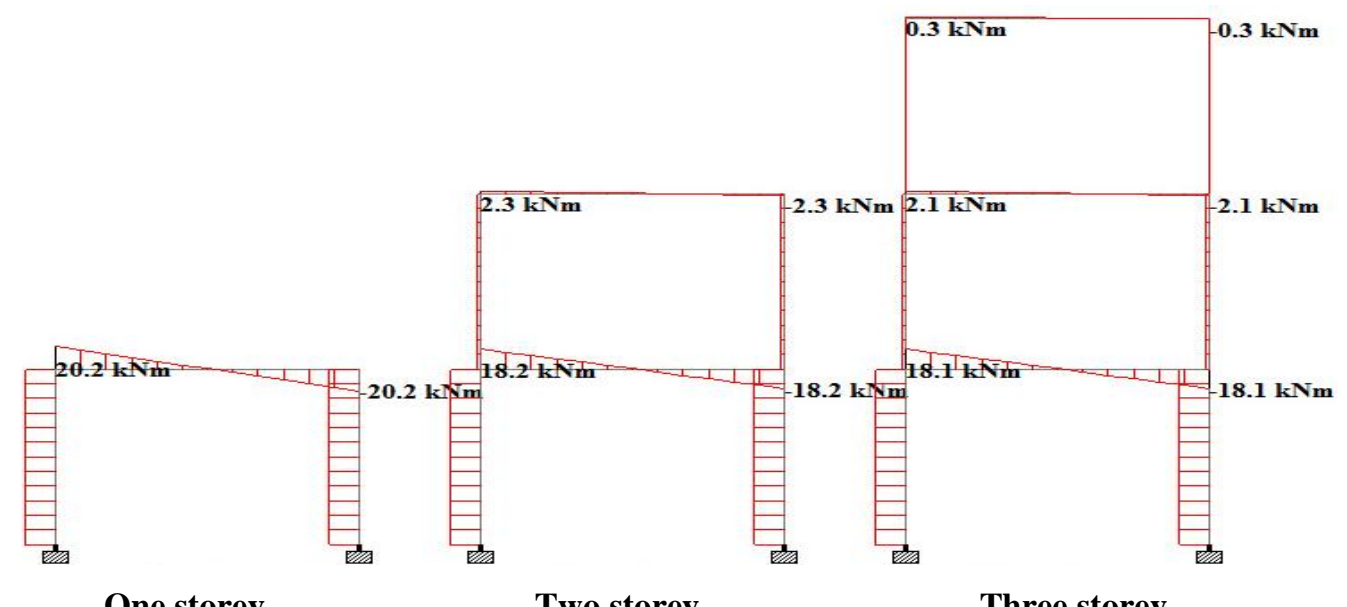

One storey

Three storey

(c) Bending moment diagram

Fig -6: Variation of forces in frame for different number of storeys 


\subsection{Effect of number of bays on frame forces}

Three models of one, two and three bays are considered to study the effect of number of bays on frame forces. The variation of axial force, shear force and bending moment with number of bays is shown in Fig 7. It is found that the effect of differential settlement on frame forces is higher for two bays as compared to one bay because the two bay system provides more stiffness due to continuation of beam. However, force pattern in two bay and three bay frame is found to be similar. The effect of differential settlement on frame forces decreases for the bays located far from the support subjected to settlement.

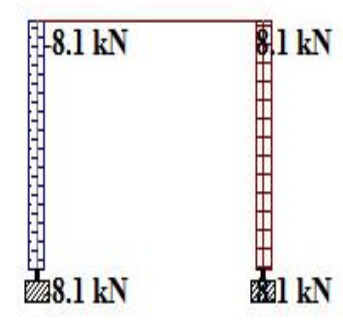

One bay

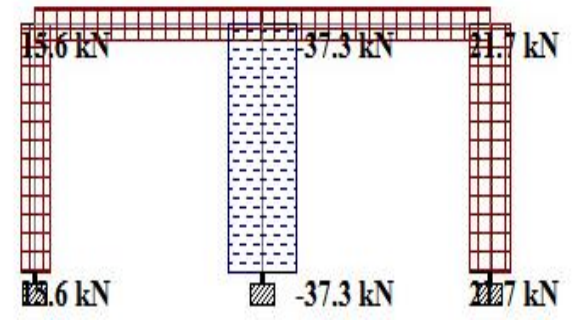

Two bay

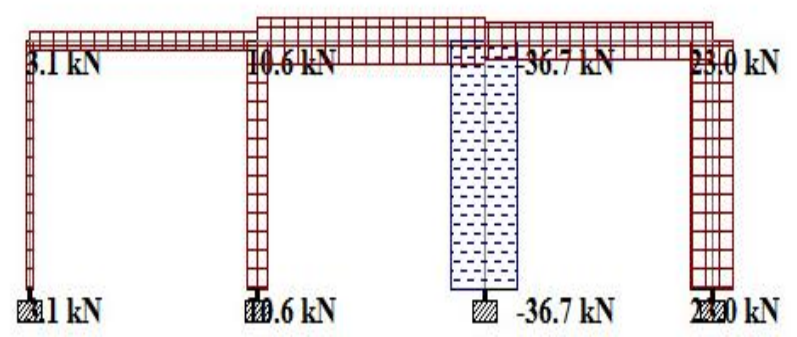

Three bay

(a) Axial force diagram

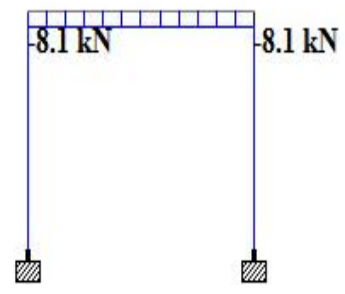

One bay

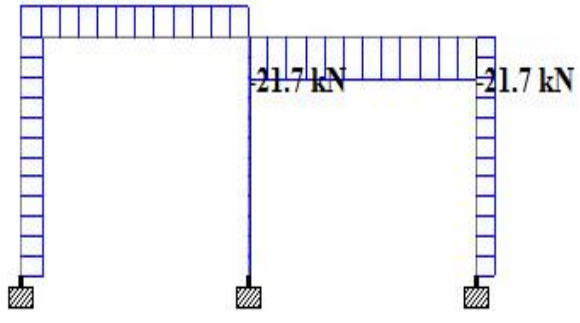

Two bay

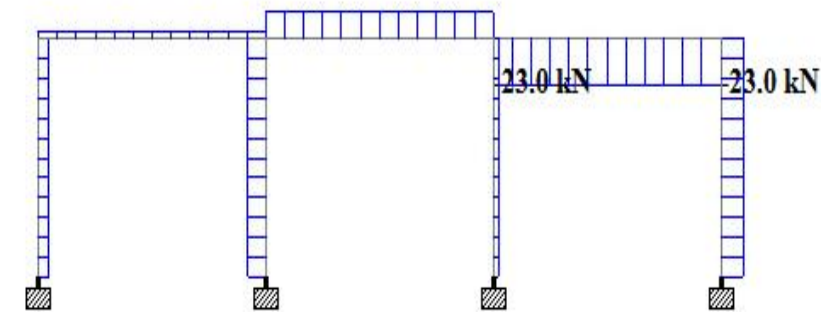

Three bay

(b) Shear force diagram

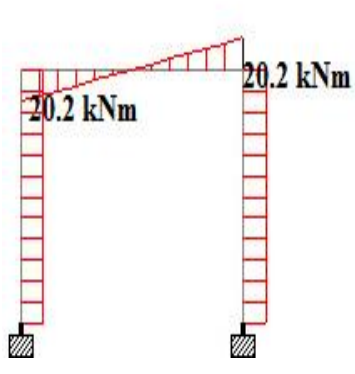

One bay

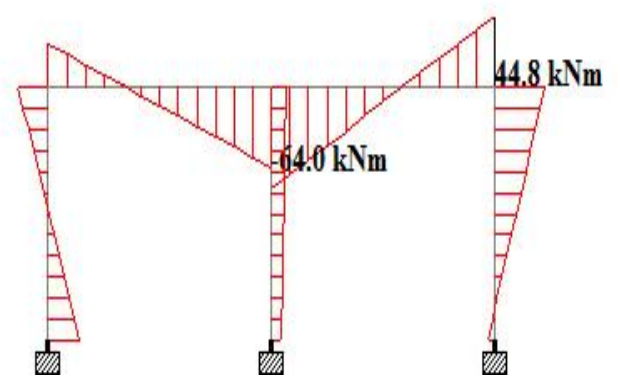

Two bay

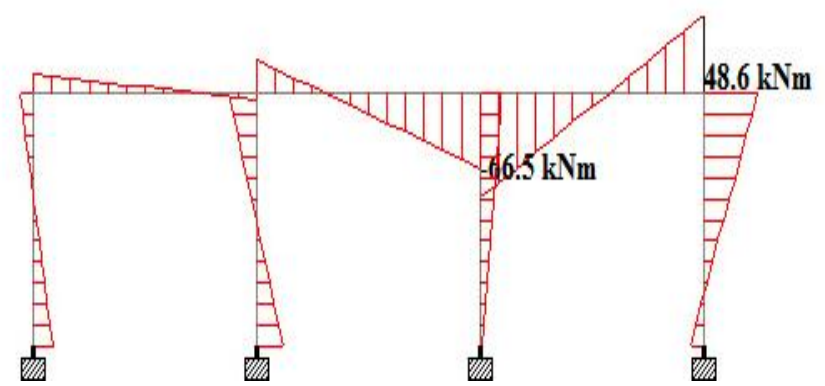

Three bay

(c) Bending moment diagram

Fig -7: Variation of forces in frame for different number of bays 


\section{CONCLUSIONS}

Effect of different structural parameters like stiffness of columns and beams and number of storeys and bays affect the frame forces developed due to differential settlement.

a) The effect of differential settlement is more prominent in frames having beams of shorter span as compared to longer span. Similarly, the effect of differential settlement is more prominent in frames having columns of lesser height.

b) The beams and columns having greater moment of inertia attract more structural forces for a constant differential settlement.

c) The effect of differential settlement on frame forces is more prominent for lower stories and this effect diminishes rapidly in higher storeys.

d) The effect of differential settlement is much higher for two bay frame as compared to one bay frame. This is because two bay system provides more rigidity due to the continuation of beam. Moreover, frame forces are more prominent for bays which are near to the support subjected to settlement.

The increase or decrease in frame forces due to differential settlement can be attributed to the change in stiffness of the members. Hence, it can be concluded that stiffer members tend to develop higher forces for constant differential settlement in frame.

\section{REFERENCES}

[1]. Meyerhof G (1947), "The settlement analysis of building frames", The structural engineer, Vol. 25, No. 9, pp. 369-409.

[2]. DeJong J. and Morgenstern N.R. (1971), "The influence of structural rigidity on the foundation loads of the CN tower, Edmonton", Canadian geotechnical journal, Vol. 8, No. 4, pp. 527-537.

[3]. Man L.K. (1977), "Performance of reinforced concrete frames subjected to differential settlement", Ph.D. thesis, Department of civil engineering, University of Hong Kong.

[4]. D'Orazio T. and Duncan J. (1987), "Differential settlements in steel tanks", Journal of geotechnical engineering, Vol. 113, No. 9, pp. 967- 983.

[5]. Dutta S.C., Maiti A. and Moitra D. (1999), "Effect of soil-structure interactions on column moment of building frames", Journal of the institution of engineers (India), Vol. 80, pp. 1-7.

[6]. Roy R. and Dutta S.C. (2001), "Differential settlement among isolated footings of building frames: the problem, its estimation and possible measures", International journal of applied mechanics and engineering, Vol. 6, No. 1, pp. 165-186.

[7]. Agrawal R. and Hora M. S. (2010), "Effect of differential settlements on nonlinear interaction behaviour of plane frame-soil system", ARPN Journal of Engineering and Applied Sciences, Vol. 5, No. 7, pp. 75-87.
[8]. Smit G. (2010), "The behavior of modern flexible framed structures undergoing differential settlement", Ph.D. thesis, School of Civil Engineering and the Environment, University of Southampton.

[9]. Le T.M.H., Gallipoli D., Sanchez M. and Wheeler S. (2013), "Rainfall-induced differential settlements of foundations on heterogeneous unsaturated soils", Géotechnique, Vol. 63, No. 15, pp. 1346-1355.

[10]. Reddy C.R. and Rao G.T.D. (2014), "Effect of Rigidity of Plinth Beam on Soil Interaction of Modeled Building Frame Supported on Pile Groups", Civil engineering dimension, Vol. 16, No. 1, pp. 8-17.

[11]. Sneha I.L., Balaji K.V.G.D. and Kumar P.C. (2014), "Study on vertical settlement and lateral displacement in different types of soils", International journal of engineering and technical research, Vol. 2, No. 9, pp. 107-111.

[12]. Lin L., Hanna A., Sinha A. and Tirca L. (2015), "Structural response to differential settlement of foundations", Journal of civil engineering research, Vol. 5, No. 3, pp. 59-66.

[13].Paixao A., Fortunato E. and Calçada R. (2015), “The effect of differential settlements on the dynamic response of the train track system: A numerical study", Engineering structures, Vol. 88, pp. 216-224. 